\title{
A Review of Solar Dehydration of Onion Slices in Developing Countries
}

\author{
Asim Osman Elzubeir \\ Faculty of Agricultural Science, University of Dongola, Dongola, Sudan \\ e-mail:asimosman11@ymail.com
}

\begin{abstract}
The appropriate drying of crops is an essential step towards the minimization of post-harvest losses; further, the improvement of quality of products by drying, and hence an increase in the price, is of tremendous economic significance to the agricultural community. Among the several methods of long-term preservation of bulb onion (Allium cepa L.) dehydration is perhaps the simplest method that does not require sophisticated equipment or highly skilled workers. Traditional dehydration in the sun poses some problems, therefore, it is necessary to consider solar dehydration of onion. Different models of solar dryers had been developed and good quantum of research is progressing in most countries to propagate the solar drying technology for value addition of bulb onion. This review paper discusses reduction of post-harvest losses of bulb onion in developing countries using solar dehydration, special attention was given to Sudan.
\end{abstract}

Keywords: Allium cepa L., post-harvest losses, solar drying.

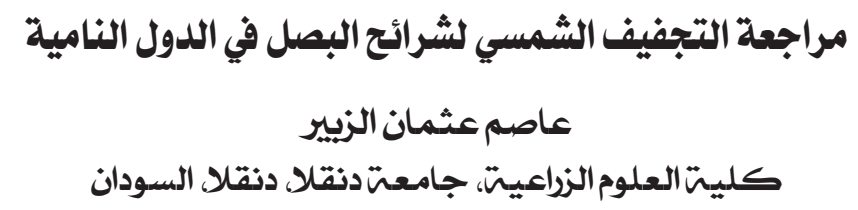

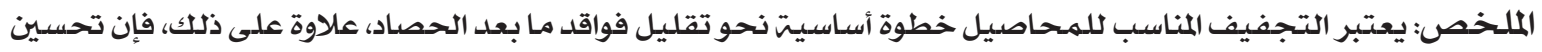

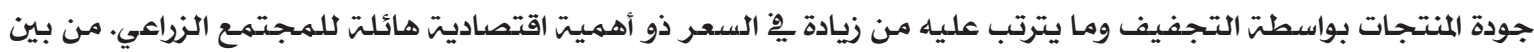

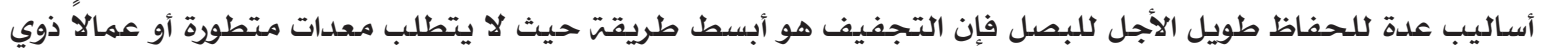

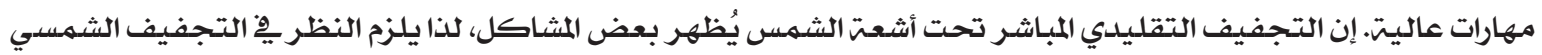

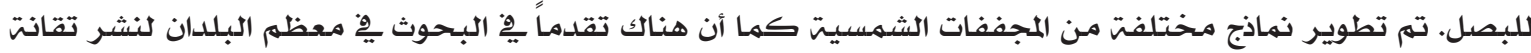

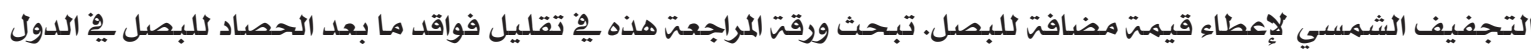
الناميتة باستخدام التجفيف الشهمسي، مـع إعطاء اهتهمام خاص بـالسـودان. 


\section{INTRODUCTION}

The developing countries suffer heavy losses of food in the post-harvest period during which the harvested crop passes through a series of well-defined steps- like threshing (or shelling), drying, storage and final processing. Estimations of these losses are generally cited to be around $40 \%$ but can, under adverse conditions, be nearly as high as $80 \%$. A significant percentage of these losses are related to improper and/ or untimely drying of foodstuffs [1,2]. The lack of technical and socio-economic information on alternative or improved food processing technologies available to people living in rural areas of developing countries means that much food gets wasted [3]. Postharvest losses represent more than just a loss of food. World Resources Institute Report [4], indicates that when $20 \%$ of a harvest is lost, also wasted is $20 \%$ of all factors that contributed to producing the crop, namely, $20 \%$ of the land used to grow the food and $20 \%$ of the water used to irrigate it along with the human labour, seeds, fertilizers, etc. Thus, post-harvest food loss translates not just into human hunger and financial loss to farmers but into tremendous environmental waste as well, the report concludes.

\section{NEEDS FOR DRYING}

Post-harvest losses of agricultural products can be drastically reduced by using proper drying techniques. Also, most agricultural crops within the developing countries are grown and harvested once a year and are limited in many countries to certain localities, the moment when these products are needed does not however usually correspond with the harvesting season. Also, there is the dent in food production caused by crop-failures as well as significant seasonal fluctuation in availability. Therefore, storage plays a crucial part in the provision of agricultural products at the desired time. Several storage techniques exist, with drying being the commonly used traditional technique. Drying is one of the oldest methods of preserving agricultural products from losses accruing in storage and on the field.

\section{BULB ONION; THE SCOPE OF THE REVIEW}

The onion is the oldest vegetable crops known to man; it is called "the queen of vegetables" by some gourmets because of its strong taste. It probably originated in Middle Asia and the regions around the Mediterranean Sea, cultivated mainly in the tropical countries, which account for nearly $30 \%$ of total global production [5]. It is used both in the raw and mature bulb stages as vegetable and spice and as a useful food for cattle and poultry, also it has significant therapeutic values. The common bulbs (Allium cepa L.), grown for the use in dry conditions belong to the family Alliaceae. The onion is generally a biennial plant, but it is grown as an annual. The bulbs may be white, yellow, red or intermediate colours [6]. A global review of area and production of major vegetables shows that onion ranks second in area of vegetables and third in production in the world, among seven 
vegetables, namely onion, garlic, cauliflower, green peas, cabbage, tomato and green beans [7].

Most of the world production of onions is lost as post-harvest spoilage. The causes of these losses are: physical injury, greening, root growth, sprouting, diseases and other injuries. Dehydration is considered as one of the oldest and most vital methods of onion processing. Popularity of dehydrated onions is increasing nowadays and is becoming a product of considerable importance in international agricultural trade. India is the largest exporter of dehydrated onions followed by Netherlands and Spain. Germany is the largest importer of dehydrated onions followed by UK and USA [8].

\section{DRYING METHODS}

Onion slices are generally dried from an initial moisture content of about $86 \%$ (w.b.) to $7 \%$ (w.b.) or less for efficient storage and processing [9]. Drying of onion slices, can be done by the following methods:

a. Natural (Sun) drying: It is the most common method and involves simply laying the product in the sun on mats, roofs or drying floors and exposing it to the combined action of the sun's radiation and the wind. However, this method can be classified into two categories: open-air sun drying and shade drying. This simple and basic approach of sun drying has the advantages of being very cheap, ideal for products where little or no value is added and the product can usually be dried close to home. However, this method is unsatisfactory for a number of reasons $[10,11]$ : i) the biggest disadvantage is lack of control over the drying rate and quality, it is not possible to ensure uniform rate and quality of drying, ii) over drying: this can easily occur in arid regions due to excessive exposure to sun or heat, and can cause bleaching, scorching, dislocation and nutritional changes, iii) very rapid drying of the crop with high moisture contents also causes damage, i.e. hardening followed by bursting, v) under drying or slow drying (a problem in humid regions) results in deterioration of food due to fungi and bacteria, vi) there is spoilage due to birds, insects, rats, etc. and vii) the yield losses due to bad climatic conditions like rain and storm, in addition to handling losses.

b. Artificial drying: Depending on product characteristics, artificial drying can be done in many different ways. In this drying method, the water is extracted from the product by providing energy- contained in the air- for the water's transition from liquid to gaseous phase. This vapour is then carried along with the ventilation air steam, and disposed off in the atmosphere outside the dryer; the drying process is carried out under controlled conditions [12]. The dryers are equipped with a regulation system for drying temperature, air velocity, as well as the relative humidity, which should be strictly controlled to ensure final product is of satisfactory quality [13].

\section{SOLAR DRYING}

Crop drying is the second biggest user of energy in crop production [14]. Therefore, crop drying is an energy intensive operation that will be increasingly affected by the 
growing conventional energy shortage. Solar energy is believed to be one of the most promising of the alternative supplementary energy sources that may cope up with the problem [15], most beautiful advantage is pollution free method and reducing emission of carbon particles in atmosphere. Also, it is extremely difficult and in most cases impossible to process and preserve high moisture content crops by normal open sun drying. Solar dryer or solar dehydrator, the device in which air is heated by solar energy, is the most viable option for most developing countries, which are within the belt of good solar radiation. Solar energy dryers usually employ higher air flow rates at a low temperature over a long drying period, in comparison to fossil fuel fired systems which use high temperatures and low air flow rates for rapid drying [16]. The controlled drying in a solar dryer, means controlling the drying parameters like drying air temperature, humidity, drying rate, moisture content and air flow rate. A solar dryer must be designed carefully keeping in mind all the mentioned parameters. The bulk of moisture from onion slices is removed by dehydration under controlled conditions, in a manner, which would ensure the effective preservation of the colour, flavour, texture and food value of onions.

Since there are many options in the design of the solar dryers, there is large variety of solar dryers [10]. Several types of solar dryers have been developed $[17,18,19$, 20]:

- Direct solar dryers; the product is exposed directly to sun radiation and absorbs it,

- Mixed solar dryers; in addition to the direct sun-exposure of the product, the drying air is preheated in a solar air heater,

- Indirect solar dryers; the drying air is preheated by a solar collector.

Dryers could also be classified into active and passive dryers [21]. Circulation in the passive dryer is caused by buoyancy from the heated air. In active dryers, a fan is creating the air movement, and these systems are called forced convection dryers.

Specialized dryers are often designed to fit specific products optimal drying conditions. In the developing countries, solar crop dryers have been experimentally studied for many decades. In addition to reduced drying, better quality produce and reduced crop losses have often resulted. A large number of dryers have been tested to dry a variety of crops including among others grain, fruits and vegetables [22], but these are not popular in rural areas due to high costs, technical know-how, or lack of skill to use these dryers [11].

The selection of dryers for food stuffs is more critical as the selected dryer should be good in both ways; the quality as well as the cost involved. The economic consideration, environmental concerns and product quality aspects are the main three fold goal of solar drying research in food processing. Concerning past failure of efforts to introduce renewable energy technologies into rural areas, several reasons 
were suggested: poor workmanship, poor resource assessment, poor training and not leaving in place managerial capability [23]. A suitable solar dryer for the rural poor should be of low cost and relatively simple to install and to maintain. A comprehensive review of the various designs, details of construction and operational principles of the wide variety of practically- realized designs of solar- energy drying systems reported previously is presented. Several techniques were developed for solar drying of onion slices, special attention was given to the solar drying technologies in the developing countries, a few of the successful small-scale installations are included, Figures 1-8.

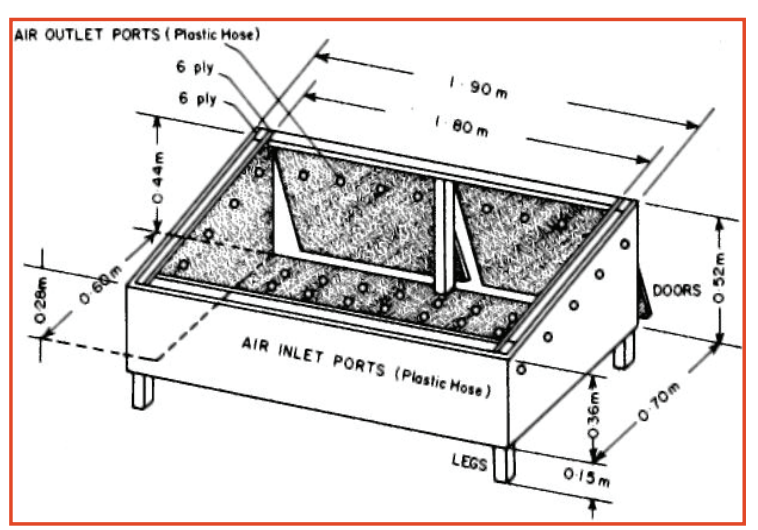

Figure (1). Solar cabinet dryer for drying onion, bitter gourd, potato and turnip [24].

The dehydrated onion shall be prepared from clean sound bulbs of suitable varieties, after proper washing, peeling, trimming and slicing. They should not be blanched since this destroys flavour and they do not require sulphiting [32, 33]. Onion bulbs are generally chopped into desired sizes and shapes using a knife. Many commercial devices are also available for chopping onions.
White cultivars are most commonly used to facilitates processing, yellow cultivars are used only for special purposes [34].
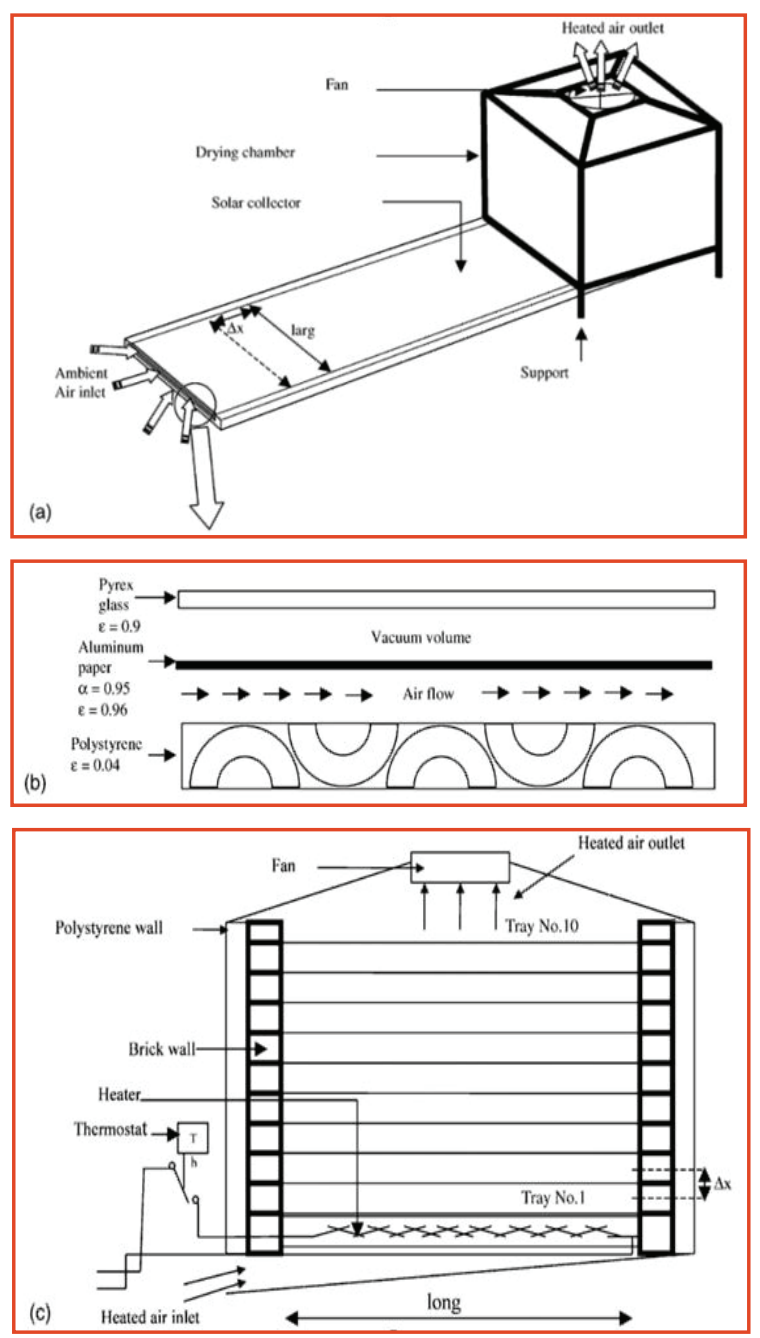

Figure (2). (a) Diagram of a solar batch dryer for onion slices. (b) Diagram of the collector. (c) Internal diagram of the dryer chamber [25].

It is very important when dehydrating onion slices to have a final product that meets with consumer acceptance, and it is desirable that the final product retains many of the flavour characteristics of the fresh onion; severe heat treatments are avoided to protect the sensory quality of dehydrated product [33]. 


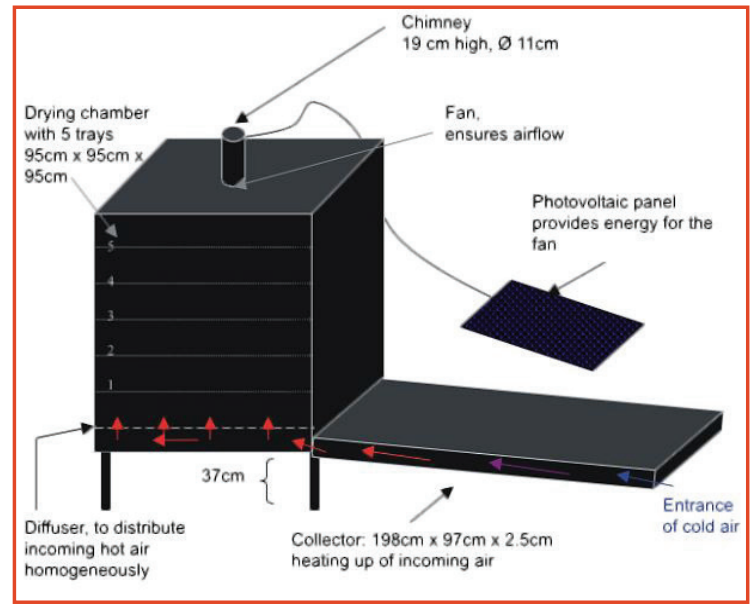

Figure (3). Forced convection dryer for onion and tomato [26].

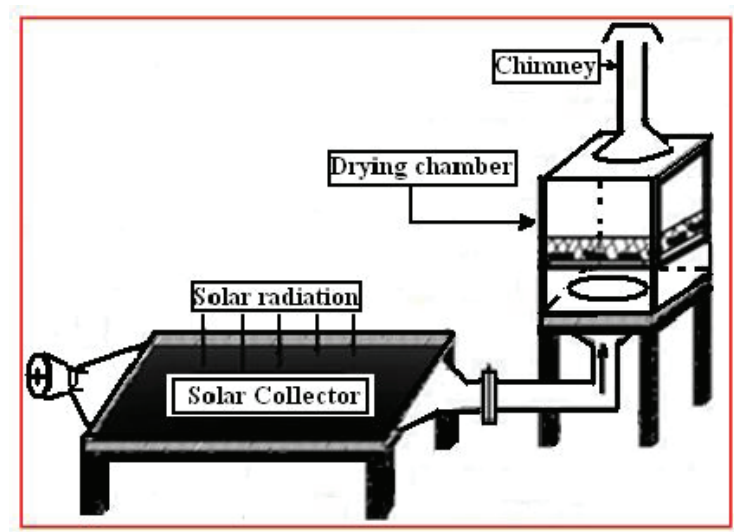

Figure (4). Schematic diagram of the solar dryer for dehydration of onion slices [27].

Dried onion is marketed in the form of slices, granules and powder. The dehydrated onion shall be packed in clean and sound containers made of material which does not affect the onion and protects it from the uptake of moisture and exit of flavour components by way of permeation [5], overall nutritional study indicates that there is minimum loss of nutrient in onion during drying process and storage, up to one year [35].

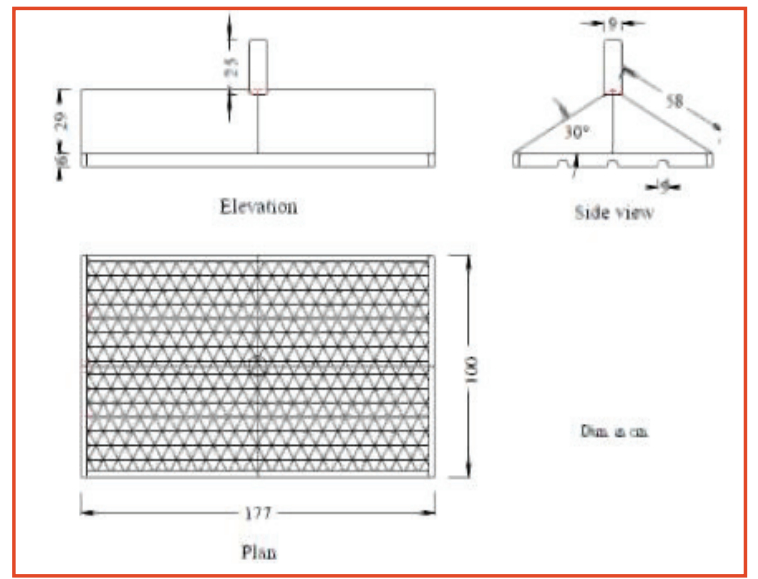

Figure (5). The gable-even span shape greenhouse solar dryer for onion flakes [28].

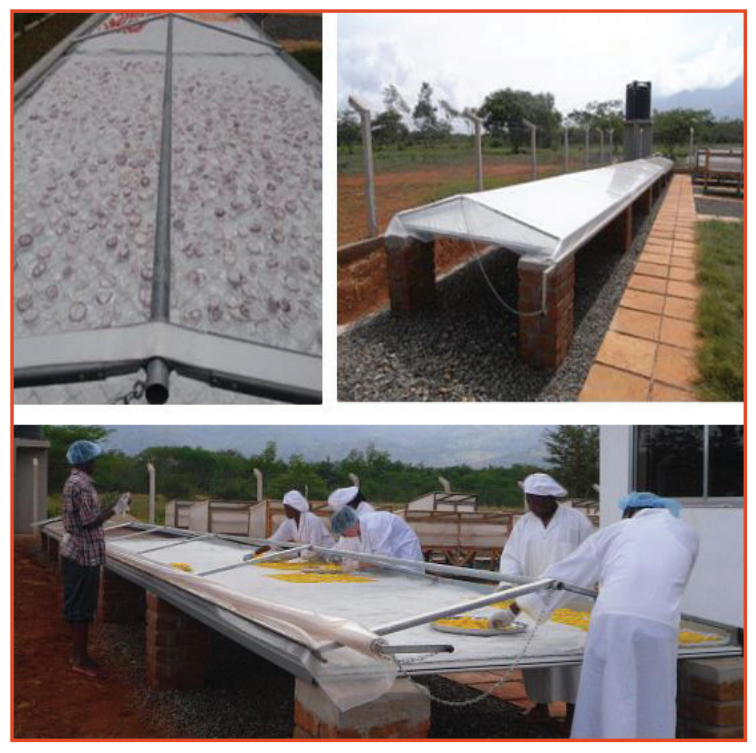

Figure (6). The tunnel dryer used for drying onion, tomato and carrot [29].

\section{SOLAR DRYING OF SLICED ONION IN THE SUDAN}

Common bulb onion is one of the most popular and widely grown vegetables in the Sudan. It is cultivated in about 33\% of the total vegetable cultivated area [36]. Recently, high yielding and good quality onion cultivars were released in the Sudan 
[37]. Onion is produced in all Sudan regions [38], the main season being the winter, the period of October-April, for market, limited dehydration and export. Another farmer group grows onion as an early crop, during June-January period. A third farmer group grows onion as late crop during NovemberJune for storage [39]. It is of great importance as the farmer is assured of high returns from cultivation even on a small area, but income is normally minimal because of inadequate conservation and storage facilities and lack of marketing structures.

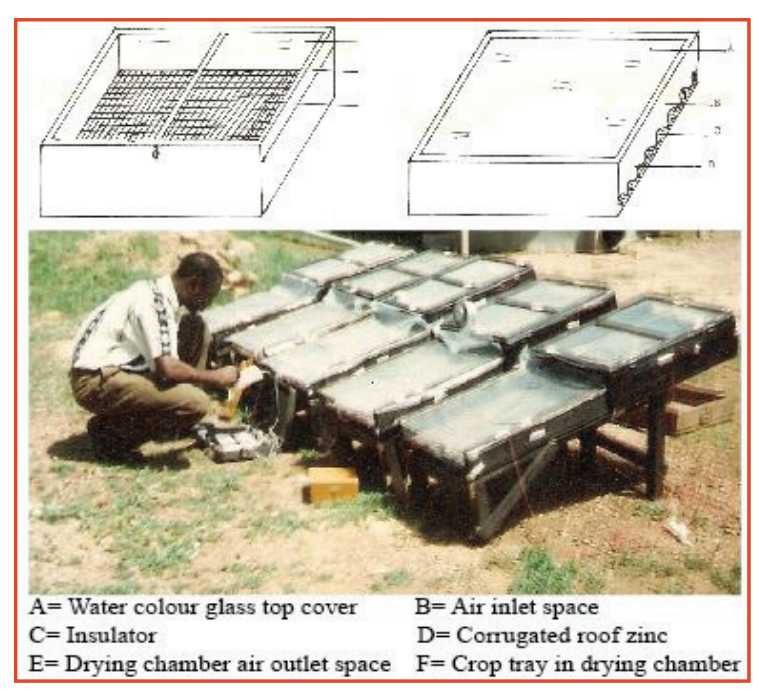

Figure (7). Schematic of assembled direct mode natural convection solar dryer for onion, tomato, okra, carrot and mango [30].

Drying is one of the oldest methods of food preservation in the Sudan. Traditional drying of fresh produce, that is largely by open drying in the sun is practiced widely. Generally, however, a number of problems have to be overcome before traditional sun drying can have a national impact, either to improve local food supplies or to generate foreign exchange earnings.

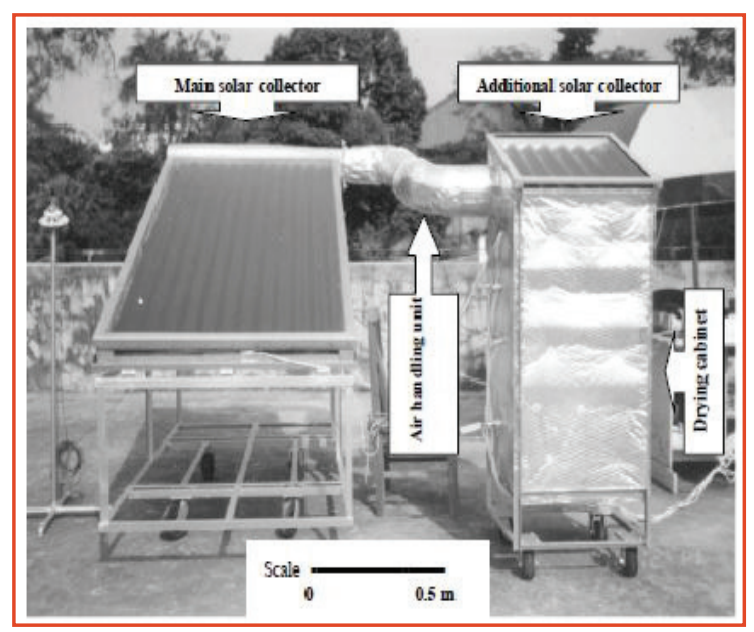

Figure (8). Small-scale solar dryer used to dry sliced onion [31].

In the Sudan dehydration industry of onion dates back to 1965 when an onion dehydration factory was established at Kassal, a famous onion region in Eastern Sudan [40]. As is known, the price of the fossil fuels and electricity, which provide heat energy for drying, is comparatively high in the Sudan. Considering Sudan is blessed with abundant sunshine, many attempts have been directed towards the use of the solar energy as a heat source for crop drying. The revival of solar drying of the more perishable agricultural products including bulb onion appears to be promising methods of reducing post-harvest losses, improving rural incomes along with contributing to self-sufficiency, and even reducing some imports through substitution products.

Renewed efforts at reviving the solar drying are now being embraced in the Sudan, but solar drying is still at the infancy stage in the Sudan. A solar dryer is a simple, cost-effective way to preserve a variety 
of different crops. A natural convection solar dryer for drying of onion slices was constructed in Sudan University of Science and Technology (Khartoum, Sudan) (Figure 9), the solar dryer heated the drying air and reduced relative humidity of the inlet air of the solar collector satisfactorily [41].

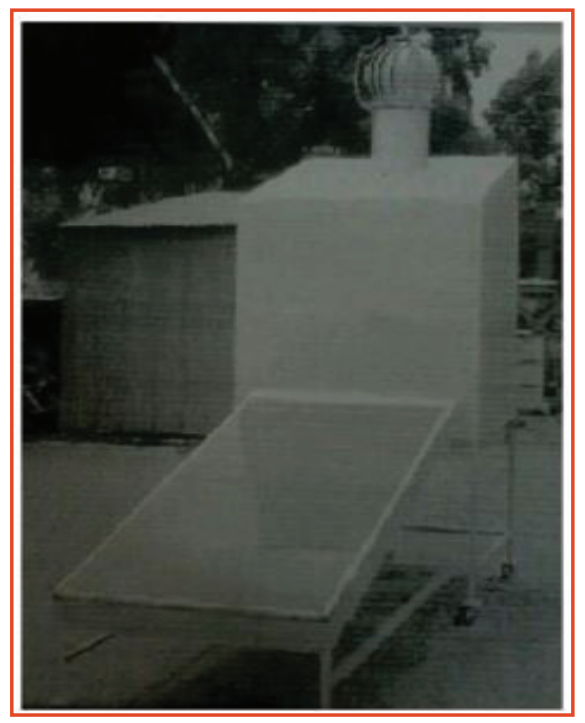

Figure (9). Natural convective solar dryer for drying of onion slices [41].

Research was conducted in University of Khartoum (Khartoum, Sudan) to accelerate drying process of onion slices using simple solar collector [42]. Improving traditional trays of $48 \mathrm{~cm}$ diameter by modifying as solar collectors painted in non-shining black without cover were used. Black painted trays improve drying performance, reduce drying time and maintain commodity quality. They do not affect final product colour, flavour or taste, the researcher concluded. This practice is highly recommended for households due to its simplicity, practicability and efficiency.

A solar dryer based on the principle of natural convection used for drying vegetables (Onion, okra and tomato) and fish was developed [43]. The constructed dryer, comprises of three main models, solar collector (tent of polythene sheet collector), drying chamber and solar chimney (Figure 10).

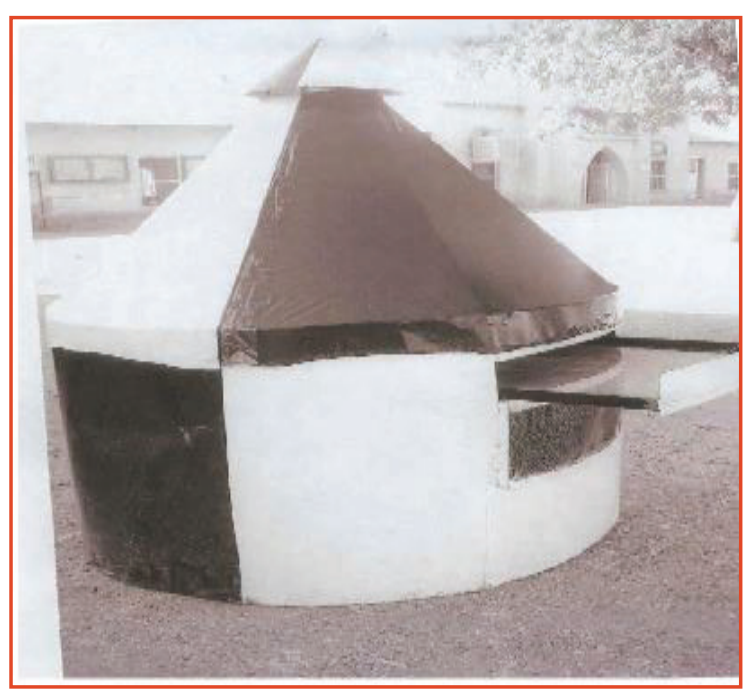

Figure (10). Polythene solar dryer for onion, okra and tomato [43].

\section{CONCLUSION}

Various topics in solar drying of onion slices are discussed in scientific reports, a review of solar dehydration of onion slices reveals that solar dryer is the best alternative technology to avoid disadvantages of conventional drying methods. The advantages of dehydrated onion slices include reduction in cost of transportation due to reduced size of dehydrated onion products and avoidance of mass loss of onion bulbs during storage due to its high perishability. In addition, dehydrated onion slices are more uniform in flavour than fresh ones. When kept in cool, dry and moisture proof containers, it can be stored for long periods 
of time. Therefore, onion dehydration is a solution for reducing storage losses and costs, as well as transport costs, ensuring a later expiration date.

\section{REFERNCES}

[1]. Bassey M.W. Development and use of solar drying technologies. Nigerian J. of Solar Energy, 89: 133-164, 1989.

[2]. Togrul I.T. and Pehliven D. Modeling of thin layer drying kinetics of some fruits under open-air sun drying process. J. Food Eng., 65: 413-425, 2004.

[3]. ILO. Solar drying: Practical methods of food preservation. International Labour Office, Genève, 1986.

[4]. World Resources Institute (WRI). Disappearing food: How big are post-harvest losses. WRI, Washington, 1998.

[5]. Linus U. Opara. Onions: Post-harvest operations. FAO, 2003.

[6]. Salunkhe D.K. and Desai B.B. Post-harvest biotechnology for vegetables Vol. 2. CRC Press Inc., Boca Raton, 1984.

[7]. Alam M.M., Islam M.N. and Alam M.N. Effect of process parameters on the effectiveness of osmotic dehydration of summer onion. International Food Research J., 20(1): 391396, 2013.

[8]. Dev Raj, Subanna V.C., Ahlawat O.P., Pardeep Gupta and Huddar A.G. Effect of pre-treatments on the quality characteristics of hydrated onion rings during storage. J. of Food, Agriculture and Environment, 4(1): 30-33, 2006.

[9]. Mitra Jayeeta, Shrivastava S.L. and Rao P.S. Onion dehydration: a review. J. of Food Sci. Technol., 49(3): 267-277, 2012.
[10]. Garg H.P. Status and prospects of crop drying. Proceeding of the $1^{\text {st }}$ World Energy Congress, Reading, UK, 23-28 September 1990. Pergamon Press, Oxford, 2: 618-628, 1990.

[11]. Aggarwal R.K. Indirect solar drier for drying of Hill products. Asian Journal of Agriculture and Rural Development, 2(2): 201-205, 2012.

[12]. Goedseels V., Stuyft E. Vander, Avermaete U., Buis H. and Palz W. New perspectives for energy saving in agriculture, current progress in solar technologies Vol. 2. D. Reidel Publishing Company, Dordrecht, 1986.

[13]. Prabhu P.V. and Balachandran K.K. Drying of fish in India. Food drying: Proceeding of a workshop held at Edmonton Alberta, 6-9 July 1981. Alberta Department of Agriculture, Edmonton, 1981.

[14]. Ritchie James D. Sourcebook for farm energy alternatives. Mc Graw-Hill Book Company, New York, 1983.

[15]. Garg H.P., Bandyopadhyay B., Sharma V.K. and Bhargava A.K. Experimental study and theoretical modeling of solar air heater for agricultural use. Proceeding of the International Solar Energy Society Congress, Brighton, England, 23-28 August 1981. Pergamon Press, Oxford, 1982.

[16]. Sodha M.S. and Chandra Ram. Solar drying systems and their testing procedure-a review. Pergamon Press, Oxford, 1994.

[17]. Schepens G., Mahy D., Buis H. and Plaz $W$. Solar energy $R$ and $D$ in the European community Vol. 1. D. Reidel Publishing Company, Dordrecht, 1986.

[18]. Van't Land C.M. Industrial drying 
equipment: Selection and application.

Marcel Dekker, New York, 1991.

[19]. Mujumdar A.S. Handbook of Industrial drying, $2^{\text {nd }}$ Edition. Marcel Dekker, New York, 1995.

[20]. Mujumdar A.S. Guide to industrial drying: Principles, equipments and new developments, $3^{\text {rd }}$ Edition. Three S Colours Publications, India, 2008.

[21]. Sharma A., Chen C.R. and Vu Lan N. Solarenergy drying systems: A review. Renewable and Sustainable Energy Reviews, 13(6-7): 1185-1210, 2009.

[22]. Malik M.A.S. Agricultural application of renewable energy sources. Proceeding of the International Solar Energy Society Congress, Brightton, England, 23-28 August 1981. Pergamon Press, Oxford, 1982.

[23]. Lawand T.A. Renewable energy application in agricultural processes. Proceeding of the International Solar Energy Society Congress, Brighton, England, 23-28 August 1981. Pergamon Press, Oxford, 1982.

[24]. Maqbool A., Hauser J.C., Heijnen C. and Chaudry M.A. Solar drying of fruits and vegetables. Pakistan J. Agric. Res., 17(3): 237244, 2002.

[25]. Bennamoun L. and Belhmari A. Design and simulation of a solar dryer for agricultural products. Journal of Food Engineering, 59(2003): 259- 266, 2003.

[26]. Troeger K., Hensel O. and Buerkert A. Conservation of onion and tomato in NigerAssessment of post-harvest losses and drying methods. Conference on International Agricultural Research for Development, University of Kassel- Witzenhausen and
University of Götingen, 2007.

[27]. Abdel-Galil H.S. and Mourad R.I.A. A solar dryer performance of onion slices under Fayoum climatic conditions. Misr J. Ag. Eng., 26(2): 953-976, 2009.

[28]. Kassem A.M., Habib Y.A., Harb S.K. and Kalil K.S. Effect of architectural form of greenhouse solar dryer system on drying of onion flakes. Egpt. J. Agric. Res., 89(2): 627638, 2011.

[29]. Strom K. Product quality in solar dried carrots, tomatoes and onions. M.Sc. thesis. Norwegian University of Life Sciences, 2011. Available at: http://www.brage.bibsys.no/.../ Product\%20quality\%20in\%20solar\%20 dried\%20 carrots,\%20tomatoes\%20and\%20 onions.pdf.

[30]. Eke A.B. Development of direct mode natural convection solar dryer for high moisture content crops. American journal of agricultural science, engineering and technology, 1(2): 11-26, 2012.

[31]. Elzubeir A.O. Solar dehydration of sliced onion. Int. J. of Vegetable Sci., 20: 264-269, 2014.

[32]. Ba A., Banzet Ch. and Degbe J.M. Drying of onions in Niger. Food drying: Proceeding of a workshop held at Edmonton Alberta, 6-9 July 1981. Alberta department of agriculture, Edmonton, 1981.

[33]. Garcia Elisabeth, Marisa Alviar-Agnew and Diane M. Barrett. Residual pectinesterase activity in dehydrated onion and garlic products. J. of Food Processing Preservation, 26(2002): 11-26, 2002.

[34]. Arthur D. Wall, Marisa M. Wall and Joe N. Corgan. Dehydrator onion bulb weight and 
water-soluble carbohydrates before and after maturity. J. Amer. Soc. Hort. Sci., 124(6): 581-586, 1999.

[35]. Alam M. and Islam N. Nutritional study during drying and storage of dehydrated summer onion. International Journal of Research, 1(11): 881-889, 2014.

[36]. Dawelbeit S.E., Salih F.M. and Ahmed E.H. Status of fertilization and crop nutrition in irrigated agriculture in Sudan 2: Main crops consuming fertilizers and the role of education in optimizing fertilizer use. Research Findings: E-ifc, No. 23, 2010.

[37]. Ali A.M., Abdel Rahim O.S. and Mohamed G.H. Effects of inter and intra row spacing on yield and quality of two onion cultivars grown under Kassal and Gash conditions, 2010. Available at: http://www.arcsudan.sd/ arc/conferences/meetings48/pdf/7.pdf.

[38]. Abdelaziz H. Economics of onion production in the Northern part of Omdurman province, Khartoum State. Albuhuth, 12(1): 42-51, 2008.
[39]. Elhasan M.M., Abdalla I.F. and Ibrahim A.A. Economics of onion production under cooperative and private schemes in Khartoum North, Sudan, 2015. Available at: http://www.economia.unipv.it/naf/.

[40]. Mohamedali G.H. Effect of plant population densities on yield and quality of white dehydration onion in the Northern Sudan, 1988. Available at: http://www.arcsudan.sd/.

[41]. Abdelrazig M.A. Evaluation of natural convection solar dryer for onion slices drying. M.Sc. thesis. Sudan University of Science and Technology, 2009.

[42]. Ahmed M.H. Improving traditional method for onion drying, 2009. Available at:

[43]. http://www.research.uofk.edu/multisites/ UofK_research/.../mahasin\%20hassan.pdf.

[44]. Alyan A.A., Bukhari M.M. and Sulieman A.E. Design of a small-scale solar dryer to improve natural drying of vegetables and fish. Gezira Journal of Engineering and Applied Sciences, 7(1): 109-131, 2012. 